\title{
Group urges survey of antibiotics in animals
}

Meredith Wadman, Washington

The Union of Concerned Scientists (UCS) is calling for widescale government monitoring of the use of antibiotics in livestock. In a report released last week, it says the amounts used far exceed industry estimates and that widespread use is putting human health at risk by encouraging the development of resistant bacteria.

The report estimates that $70 \%$ of all antibiotics used in the United States are fed to healthy animals. It urges the Food and Drug Administration (FDA) and the US Department of Agriculture to compel the drug and livestock industries to report the quantities, dosages and treatment periods of all antimicrobials used on food animals.

"Which antibiotics are most in use? Have use patterns changed over time? Why? These are all very basic questions, and in the US, you can't answer them. There are no data compiled by the government either on production or use," says Margaret Mellon, the report's lead author.

The UCS, which represents about 50,000 US scientists and citizens, timed its report to influence an FDA meeting on 22 January on antimicrobial use in livestock. The report says that, without thorough and reliable data, it is impossible to combat growing antimicrobial resistance in human pathogens.

Industry has in the past resisted providing such data. Livestock and poultry producers have used low-level antibiotics non-thera- peutically in animals for decades to promote growth and prevent disease. They argue that restrictions would put meat prices up and compromise food safety.

The UCS report uses publicly available data to arrive at an admittedly approximate estimate that 24.6 million pounds $(11,200$ tonnes) of antimicrobials are fed to US poultry, pigs and cattle annually for non-therapeutic uses, an increase of 50\% since 1985 .

Industry sources dispute that number. The Animal Health Institute (AHI) in Washington, which represents the makers of animal drugs, estimated last year that 8,100 tonnes of antibiotics were used for all purposes in animals, of which only 4,200 tonnes are antibiotics also used in humans.

"The assumption is that somehow human health is being compromised," says John Keeling, who spearheaded the AHI survey. "That has not been demonstrated."

But Stephen Sundlof, director of the FDA's Center for Veterinary Medicine, says that transmission of antimicrobial-resistant pathogens from animals to humans in the food supply is an established fact, although the degree to which it occurs and the severity of the disease it causes remains in dispute.

Sundlof says that the agency has drafted regulations that will compel companies to make available most of the information that the UCS is calling for.

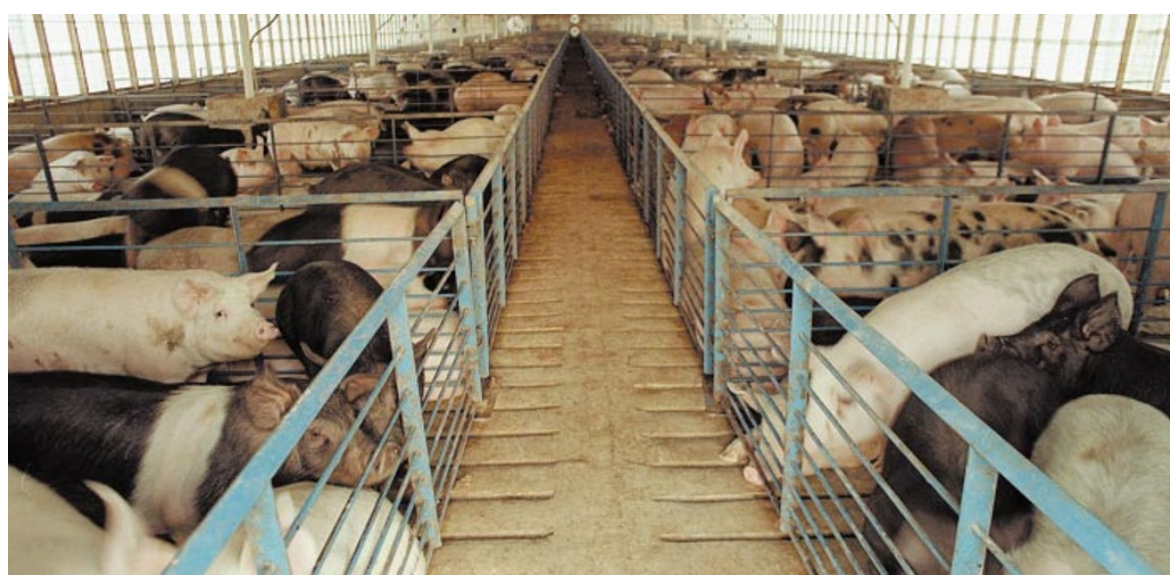

Pigging out? The widespread use of antibiotics on healthy animals might be affecting human health.

\section{French museum report sparks researchers' revolt}

\section{Declan Butler, Paris}

Researchers at the National Museum of Natural History in Paris are up in arms over a report on the future of research at the museum. The report, which is likely to determine the museum's research strategy, implies that biophysics and Earth sciences have no place in the institution.

Research should be centred around nine themes, the report says. These range from palaeontology to developmental biology, but

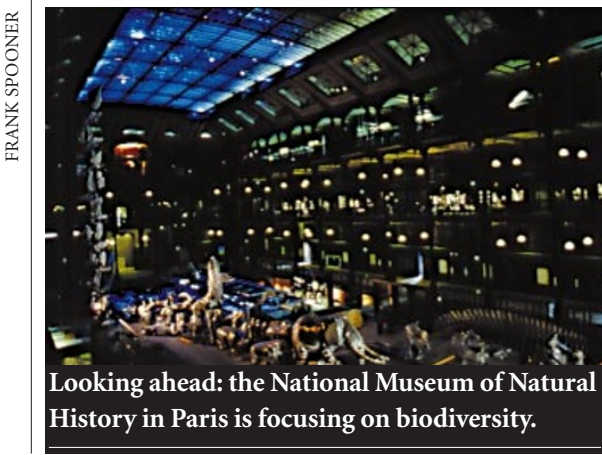

all involve studying biodiversity from an evolutionary perspective. The report was commissioned from an outside panel by the museum's interim administrator, JeanClaude Moreno, as part of a plan to reform the museum (see Nature 401, 104; 1999).

Museum staff say they were initially optimistic, but that the process has proceeded without their consultation. Trade-union representatives and professors walked out of a council meeting at the museum on 15 December after reading out a statement to Moreno saying the report inspired "deception rather than hope".

One researcher says the reforms are being managed in an atmosphere of "extreme secrecy" and that there is "enormous apathy and exhaustion" among museum staff.

Moreno has promised that researchers will have the opportunity later in January to meet the committee that wrote the report, and hopes that most elements of the reform plan will be put in place before the summer.

Thérèse Garestier, director of the biophysics lab, which the report acknowledges as a centre of excellence, says she does not understand how its work in functional genomics can be dissociated from biodiversity. She says that implementing the report would reduce her laboratory's role to servicing the museum's taxonomists.

Over 100 researchers from the four labs making up the Earth sciences department signed a motion deploring the assertion that their research has no place in the museum.

The study, they say, "demonstrates a curious interpretation of the natural sciences... with no reference to [the] past, nor to the Earth on which life developed and evolved".

The report gives top priority to securing the housing and computerization of the museum's millions of specimens.

Paul Henderson, director of science at London's Natural History Museum and the only foreign member of the committee, says the report is a great opportunity for the museum to "re-establish itself as one of the great world centres in biodiversity". 